\title{
Hungary's Latest Experiences with Article 2 TEU: The Need for 'Informed' EU Sanctions
}

\author{
Beáta Bakó
}

\section{Contents}

1 Introduction

2 The Big Picture: Targeted Legislation and Constitutional Malfunctions ................ 38

$2.1 \quad$ Lex Friends and Lex Enemies ....................................... 38

2.1.1 Turning the Data Protection Ombudsman into an Authority Influenced by

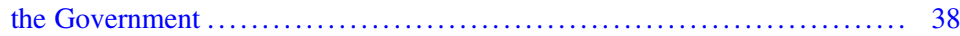

2.1.2 Sending Judges into Retirement ............................... 39

2.1.3 Labelling Foreign Funded NGOs ............................... 39

2.1.4 Targeting the 'Soros University' .................................. 40

2.1.5 'Stopping Soros' (and Migration) ............................. 42

2.1.6 The System of Lex Friends and Lex Enemies: The Fundamental Challenge to the Rule of Law in Hungary ................................... 42

2.2 Unrestrained Constitutional Amendments ............................... 44

2.3 The Constitutional Court: Still a Counterbalance or, Already an Ally of the Government? .............................................. 48

2.3.1 Filling the Court with Fidesz-Loyalist Judges ........................ 49

2.3.2 Limiting Constitutional Review in Important Cases ................. 50

2.3.3 New Strategies of the Constitutional Court: Shifting Away from the Control of the Legislative ........................................... 51

3 Why Infringement Procedures Are Ineffective in the Case of Hungary .............. 53

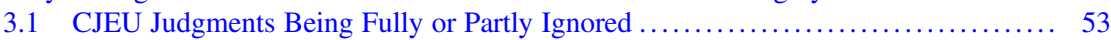

3.2 Infringement Cases Regarding the NGO Law and the Lex CEU ................ 55

4 Making a Try with Article 7: The Sargentini Report on Hungary . . . . . . . . . . . . . . . 58

4.1 Getting Lost in Details, Missing the Bigger Picture ......................... 59

4.2 Limited Political Relevance .......................................... 60

5 How to Take 'Informed' Measures in Defence of the Union's Values? ............... 61

5.1 Measuring, Buying or Monitoring the Rule of Law? ....................... 62

5.2 How to Indicate Overlapping Systemic Rule of Law Deficiencies? .............. 65

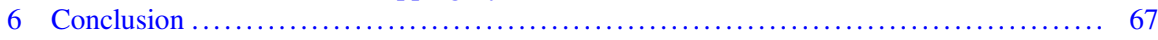

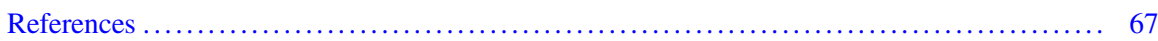

B. Bakó (四)

Department of Law, European University Institute, Florence, Italy 


\begin{abstract}
This contribution will concentrate on the Hungarian situation by analysing the generalised practice of targeted legislation and the different causes for legal uncertainty on the constitutional level. The European Parliament initiated an Article 7 TEU sanctioning procedure against Hungary in September 2018 and several infringement proceedings have been launched by the Commission. Unfortunately, these EU responses were not able to grasp the gist of the Hungarian developments. Even the so called Sargentini report of the European Parliament - intended to be a comprehensive analysis of the rule of law deficiencies in Hungary - could not identify the most significant patterns of the Hungarian rule of law decline. This reveals a central shortcoming of EU sanctioning mechanisms employed against 'backsliding' Member States: the need for 'informed' sanctions. Some recent legislative proposals for measuring the rule of law illustrate, that the need for such informed sanctions has been realised by EU institutions. However, the question of 'how' is still unanswered. Taking the case of Hungary as an example, I will finally recommend some aspects to be considered in order to grasp the patterns of 'systemic' rule of law decline.
\end{abstract}

Polak, Węgier, dwa bratanki / I do szabli, i do szklanki

Lengyel, magyar, két jó barát / együtt harcol, s issza borát ${ }^{1}$

\title{
1 Introduction
}

Today, this proverb of Polish-Hungarian friendship has developed a new meaning, as Hungary and Poland 'fight together' against the EU and its founding values as listed (but not defined) in Article 2 TEU. Both countries are shifting towards an extreme version of what Richard Bellamy termed 'political constitutionalism'. Against 'legal constitutionalism' and judicial review as one of its key features, Richard Bellamy argues that the democratic mechanisms and decision-making by majority rule offer superior and sufficient methods for upholding rights and the rule of law. The absence of popular accountability renders judicial review a form of arbitrary rule which lacks the incentive structure democracy provides to ensure rulers treat the ruled with equal concern and respect. According to Bellamy, one of the key legal constitutionalist methods is establishing boundaries for the political sphere by 'designating certain values ... as beyond the realm of politics. ${ }^{3}$

Applying Bellamy's words to the current debates revolving around the 'Copenhagen dilemma', it is hard to decide whether the current events should be framed in political or legal terms. Indeed, it seems that Article 2 TEU is at the interface of the

\footnotetext{
${ }^{1}$ 'Polish and Hungarian are two brothers [Polish]/two good friends [Hungarian]; they fight and drink together.'

${ }^{2}$ About constitutionalism as understood in the EU legal order see e.g. Glencross (2014), pp. 1165-1167; Walker (2007), pp. 254-267.

${ }^{3}$ Bellamy (2007), p. 147.
} 
political and legal realm. While the EU's founding values are clearly beyond the realm of day-to-day politics, the contours of their exact meaning and their enforcement could hardly be more politicised: Article 7 TEU is commonly labelled as a 'nuclear option'. ${ }^{4}$ Just like nuclear weapons, pressing the button is exclusively up to politicians. In this light, the defence of the Union's common values faces a twofold risk: first, the risk of becoming a highly politicised question, and second, the risk of losing the bigger picture in narrow and particularized judicial proceedings.

On one hand, politicians usually do not decide in line with constitutional concepts and ideas but rather in line with their interests. An important interest that concerns all EU Member States is to maintain peaceful relations and not to give reason for any kind of 'revenge' or 'retaliation'. The recent procedures against Poland and Hungary are testimony to this: After Poland, ${ }^{5}$ a second Article 7 TEU procedure was launched against Hungary. ${ }^{6}$ Yet, nothing moved forward in the Council. Indeed, the risk of 'mutual indulgence ${ }^{77}$ has increased especially after the Polish and the Hungarian governments enormously contributed to the nomination of the surprise candidate for the presidency of the Commission.

On the other hand, the infringement procedures brought by the Commission were unable to sufficiently address the gist of the illiberal developments in the respective Member States. They were instead, focused on particularized, individual details while leaving the systemic patterns aside.

The Hungarian example perfectly illustrates these shortcomings. Taking Hungary as a case study, this paper will reveal that systemic patterns might be complex and not always visible in the Member States. First, this contribution systematizes the developments in Hungary and reveals two crucial threats to the rule of law: on one hand, the Hungarian government established a skilfully designed, complex and nuanced system of legislation targeting specifically its 'enemies' and 'friends'. On the other hand, there are serious malfunctions on the constitutional level like the questionable use of constitutional amendments as an instrument of every-day politics and the declining role of the Constitutional Court (see Sect. 2). This analysis demonstrates how difficult it is for EU institutions to grasp these developmentsespecially in a highly politicised (Art. $7 \mathrm{TEU}$ ) or particularized legal procedure (Art. 258 TFEU). Seen in this light, it becomes clear that the developments in Hungary were only partially addressed by the Commission's infringement procedures (see Sect. 3) and the Article 7 TEU procedure initiated by the European Parliament (see Sect. 4). These procedures concentrate on specific laws without having the bigger picture in mind. What could be responses to these shortcomings? I argue that there

\footnotetext{
${ }^{4}$ Critically on the 'nuclear myth', see Kochenov (2017).

${ }^{5}$ Proposal for a Council decision on the determination of a clear risk of a serious breach by the Republic of Poland of the rule of law (2017/0360(APP), 20. December 2017.

${ }^{6}$ European Parliament resolution of 12 September 2018 on a proposal calling on the Council to determine, pursuant to Article 7(1) of the Treaty on European Union, the existence of a clear risk of a serious breach by Hungary of the values on which the Union is founded (2017/2131(INL)), P8_TA(2018)0340.

${ }^{7}$ von Bogdandy et al. (2012), p. 497.
} 
should be no procedures against 'backsliding' Member States without a profound legal assessment involving independent experts beforehand —in a nutshell: there is a need for more 'informed' EU sanctions. Some recent legislative proposals reflect the need for 'measuring' the rule of law. However, it is important that any system of indicators should follow a comprehensive approach (see Sect. 5).

\section{The Big Picture: Targeted Legislation and Constitutional Malfunctions}

\subsection{Lex Friends and Lex Enemies}

Targeted legislation can take different forms and shapes. In the first years after setting up the new constitutional system in January 2012, several independent state institutions were affected by organisational changes and this was a proper occasion to dispense with independent officials, like the data protection ombudsman (see Sect. 2.1.1), the president of the Supreme Court and 'communist judges' in general (see Sect. 2.1.2). As the years passed and the new constitutional system was consolidated, targeted legislation has diverged from constitutional institutions to everyday subjects: some of them were also useful in the political communication of the governing parties (see Sects. 2.1.3-6).

\subsubsection{Turning the Data Protection Ombudsman into an Authority Influenced by the Government}

As the new Hungarian Fundamental Law entered into force in January 2012, the office, and together with that, the term of the former data protection ombudsman was terminated and a new Data Protection Authority was established. ${ }^{8}$ Contrary to the ombudsman who had been elected by the parliament, the president of the National Data Protection and Freedom of Information Authority (NAIH) is nominated by the President of the Republic on the proposal of the Prime Minister. He may be reappointed for a second term which only strengthens his political dependency. ${ }^{9}$

\footnotetext{
${ }^{8} \S 38$ of Act CXII. of 2011 on the Right to Informational Self-determination and Freedom of Information.

${ }^{9}$ In details see also Polyák and Szóke (2011), pp. 164-165.
} 


\subsubsection{Sending Judges into Retirement}

Similar reorganisational measures have been adopted in the judiciary: new administrative organs have been established ${ }^{10}$ and the Supreme Court has been renamed 'Curia'. ${ }^{11}$ At the same time, the president of the Supreme Court was released and the Curia started its work with a new president. ${ }^{12}$ The new constitution further prescribed that 'with the exception of the President of the Curia, no judge may serve who is older than the general retirement age. ${ }^{13}$

The law on the status of judges prescribed that judges had to retire at the age of 62 instead of the former 70 . The new rule affected about $10 \%$ of the judges. ${ }^{14}$ Prosecutors and notaries had to meet the same age-requirements too. The law would have entered into force with a tight vacatio legis: half a year before the affected judges would have had to retire.

\subsubsection{Labelling Foreign Funded NGOs}

Unlike in 2012 and 2013, when the institutional reforms concerned state institutions, the Hungarian government found quite different targets by 2017. These were nongovernmental institutions: civil society organisations on one hand, and a university, on the other-moreover, only a few particular players within these specific categories were affected.

After the government started to systematically undermine the rule of law, to limit the powers of the Hungarian Constitutional Court (HCC) and to amend the constitution routinely in line with its political interests, it had received harsh criticism from civil society, particularly from different NGOs like the Hungarian Civil Liberties

\footnotetext{
${ }^{10}$ The National Judicial Office (NJO) has been established by the new Fundamental Law. It is led by its president who is elected by the parliament: accidentally, she is the wife of a Fidesz-politician and an old friend of the Prime Minister. Her most criticised competence was the transfer of cases between different courts but later this was abrogated by the fifth amendment of the constitution in autumn 2013. For details about the judiciary reform see e.g. Sonnevend et al. (2015), pp. 102-103. Since the beginning of 2017, a conflict has developed between the NJO and the self-administration body of the judiciary, the National Judiciary Council (NJC). Namely, the president of the NJO often declared applications to judicial positions as void in order to avoid the control of the NJC. The controversies in details are discussed by Vadász (2018).

${ }^{11}$ Originally: Art. 25 (1) of the Fundamental Law, due to amendments now Art. 25 (2).

${ }^{12}$ The former Supreme Court president, András Baka made a complaint before the European Court of Human Rights on the issue. The Strasbourg court dismissed Hungary on the grounds of the right to access to court and the freedom of expression. Concerning the latter, the Court found that the reason of 'the early termination of his mandate as President of the Supreme Court was not the result of a justified restructuring of the supreme judicial authority in Hungary, but in fact was set up on account of the views and criticisms that he had publicly expressed in his professional capacity on the legislative reforms concerned'. (ECHR decision no. 20261/12, Baka v. Hungary, paras. 75, 96.).

${ }^{13}$ Art. 26 (2) of the Fundamental Law.

${ }^{14}$ Szente (2017), p. 466.
} 
Union (TASZ), the Hungarian Helsinki Committee, or, the Hungarian division of Amnesty International.

Their activity must have been a thorn in the government's eye for a couple of years but the first concrete legislative step against them was linked to the migration crisis - at least on the rhetorical level. According to the government's narrative, the Hungarian-American billionaire George Soros planned to smuggle millions of migrants into Europe and is financing NGOs to fulfil this plan. ${ }^{15}$

The new law on the transparency of foreign funded NGOs was adopted in June 2017. According to the new rules, NGOs receiving more than 7.2 million HUF (approximately 24,000 Euros) from abroad per year must register themselves as 'organisations supported from abroad'. This label must be used on their website and on their materials. They were also obliged to provide detailed information to the authorities about the funding they receive. ${ }^{16}$

Some affected NGOs declared civil disobedience and refused to register themselves as being financed from abroad, emphasizing at the same time, that their financial background was already transparent. ${ }^{17}$ Several NGOs made constitutional complaints before the Constitutional Court based on personality and privacy rights and the freedom of expression. ${ }^{18}$ Additionally, opposition MPs issued a norm control procedure before the Constitutional Court, arguing that the law violated the principles of legal certainty and the rule of law and threatened the freedom of association. ${ }^{19}$ For now, all cases are pending before the Court.

\subsubsection{Targeting the 'Soros University'}

The other problematic law applies to an even narrower circle of addressees and has an important overlap with the NGO law: George Soros. The amendment of the Higher Education Law adopted in April 2017 clearly targets the Central European University (CEU) founded by the Hungarian-American billionaire. The amendment has set up new requirements for universities operating from a third country (non-EEA) to continue their activities in Hungary.

The most significant change is that an international agreement between Hungary and the third state is needed. If this is a federal state, a prior agreement with the

\footnotetext{
${ }^{15}$ The story contains truth in small and fragmented pieces in so far as the abovementioned NGOs get funding from the Soros founded Open Society Foundations and some of them offer legal aid to asylum seekers. However, it is not the only and main focus of their activity and the financing sources (including the OSF) had been published in their financial reports at their website already earlier.

${ }^{16}$ Act LXXVI of 2017 on the transparency of civil organisations financed from abroad.

${ }^{17}$ The boycott declared by HCLU/TASZ, Amnesty International and Hungarian Helsinki Committee was joined later by four further NGOs. By doing so, they are risking a fine between 10,000 and 900,000 HUF (30-3,000 Euros). For now, they have not announced being fined because of that.

${ }^{18} \mathrm{AB}$ cases no. IV/01830/2017, IV/01685/2017 and IV/01857/2017.

${ }^{19} \mathrm{AB}$ case no. II/01460/2017.
} 
federal government is required. The amendment further prescribes that the affected foreign universities must perform educational activity in their country of origin too. ${ }^{20}$ There are 27 third country universities operating in Hungary but most of them have only a few study programs together with other Hungarian universities. Conversely, the entirety of CEU's educational program has been threatened by this law. Further, this is the only university among the addressees having no campus and educational activity in its country of origin (the U.S.) at all. The sum of these special requirements has made one thing clear: the exclusive target was the 'Soros University', the CEU.

The amendment has set a tight vacatio legis: originally, the deadline for compliance with the new rules was the 1st of January 2018. However, in October 2017after an infringement procedure and several constitutional reviews had been initiated $^{21}$ - the government suddenly realised that this was not realistic and extended the deadline for one more year. ${ }^{22}$ In December 2018 the CEU announced it would move to Vienna because the Hungarian government rejected to sign or ratify the required international agreement. ${ }^{23}$

The decision on the constitutionality of the law still has not been made by the Constitutional Court. The Constitutional Court suspended the procedures of the lex CEU and the NGO law in June 2018 with a very strange reasoning. Namely, referring to the European constitutional dialogue and the obligation of cooperation within the European Union, the Court found it necessary to wait for the closing of the parallel cases pending before the European Court of Justice. ${ }^{24}$ The decision illustrates that the HCC did not (want to) acknowledge that the CJEU will decide on grounds of EU law, which is a totally different yardstick than the Hungarian constitution. ${ }^{25}$

\footnotetext{
${ }^{20} \S 2$ of Act XXV of 2017 on the amendment of Act CCIV of 2011 on the national higher education.

${ }^{21}$ The university issued a constitutional complaint and opposition politicians initiated norm control before the Constitutional Court. Both cases are still pending under case numbers II/01036/2017 and IV/01810/2017. Details about the infringement procedures in Sect. 3 below.

${ }^{22}$ Act CXXVII on the amendment of Act CCIV of 2011 on the national higher education and of Act XXV of 2017 supra note 20.

${ }^{23}$ The development that started with the lex CEU, continued in the Summer of 2019 the law on the Hungarian Academy of Sciences was amended. The most important point of the amendment is that the Academy would be deprived of its research network (Act. LXVIII of 2019). Opposition MPs initiated a norm control before the Constitutional Court (pending case no. II/01214/2019). The president of the Academy also announced to file a constitutional complaint in the matter. Since the Academy is a public institution and a part of the central budget, the reform itself does not necessarily mean that it was a lex enemy. However, such motivations cannot be excluded either, especially taking into account that the government has no visible and constructive plans for a reasonable restructuration of the Academy.

${ }^{24}$ AB orders no. 3198/2018 (VI. 21), 3200/2018 (VI. 21) and 3199/2018 (VI. 21) (ABH 2018, 1050, 1057,1064 , respectively).

${ }^{25}$ This point is however addressed in some parallel reasonings and dissenting opinions. See e.g. the dissenting opinion of István Stumpf and the parallel reasoning of Balázs Schanda and Ildikó Hörcherné Marosi to AB order no. 3200/2018, supra note 24.
} 


\subsection{5 'Stopping Soros' (and Migration)}

The latest package amending several laws related to immigration has been named 'Stop Soros ${ }^{26}$ by the government in order to link the fight against immigration and Soros stronger in their political rhetoric. However, contrary to the name, this is not a typical piece of targeted legislation (unlike the 'lex CEU' that was officially labelled the amendment of the Higher Education Law).

The package was adopted in Summer 2018, after Fidesz won a third two thirds majority in the parliament in the aftermath of the elections held in Spring 2018. The most striking point of the law is the introduction of a new criminal offense called 'facilitating illegal migration.' The offence refers to any 'organisational activity' aimed at enabling a person to file an asylum application in the event that the latter is ineligible for asylum. ${ }^{27}$ The police is also empowered to issue injunctions against persons suspected (not even accused or condemned) to facilitate illegal migration or other immigration-related offences from approaching the border closer than $8 \mathrm{~km} .{ }^{28}$ Therefore, it seems that the ultimate objective is not to condemn but rather to keep away any persona non grata from the border.

\subsubsection{The System of Lex Friends and Lex Enemies: The Fundamental Challenge to the Rule of Law in Hungary}

The above listed pieces of targeted legislation are by far not unique examples, but they are the ones that have been noticed in Brussels. However, many other targeted legislations have not triggered the EU's attention yet. One of the most striking examples of lex enemies is strongly related to the EU-values, especially to the principle of democracy. It is most commonly known as the 'billboard law' and was adopted with a procedural trick. In the summer of 2017-ahead of the 2018 elections - the parliamentary majority adopted an amendment of Act LXXIV of 2016 on the protection of the landscape. ${ }^{29}$ On its face, the law has nothing to do with political campaigns. Yet its new $\S 11 / \mathrm{G}$ prohibits parties ('organisations supported from the central budget') to advertise under a certain listed price beyond the period of election campaigns.

The new provisions clearly target opposition parties, especially Jobbik, which was supported at the 2018 elections by an investor owning several billboards. The

\footnotetext{
${ }^{26}$ Officially: Act VI. of 2018 on the amendment of certain law related to the measures against illegal immigration.

${ }^{27} \S 353 / \mathrm{A}$ of Act $\mathrm{C}$ of 2012 on the Criminal Code. It must be noted that according to the general rules of Hungarian criminal law, intentional crimes can only be committed deliberately: See Blaskó (2016). Therefore, it is not that easy to condemn someone according to this provision: it has to be proven before the court that the accused person exactly knew that the migrant he helped was safe in his home country or during his journey.

${ }^{28} \mathrm{New} \S 46 / \mathrm{F}$ of Act XXXIV of 1994 on the police.

${ }^{29}$ Act CIV of 2017.
} 
governing Fidesz, however, can easily avoid the scope of this law by labelling its advertising as 'government information' instead of party campaigning. ${ }^{30}$ The reason why this provision had to be implemented through the law on landscape protection was the fact that at that time Fidesz did not have the two-thirds majority in parliament. Both the election procedure-including the rules of campaigning - and party financing must be regulated through cardinal laws that require the support of the two-thirds majority of attending MPs. ${ }^{31}$ So Fidesz bypassed its 'own' Basic Law by hiding the rules in a piece of ordinary legislation that could be adopted with simple majority.

Besides these examples, several laws have been made to favour 'friends', to make them eligible to certain positions ${ }^{32}$ or to benefit them otherwise. The content of such lex friends may change according to who the friend is, and which position he holds. For example, the company called MAHIR was owned by an oligarch who had been an old friend of the Prime Minister: MAHIR owned several billboards in the country. A concurrent company, the ESMA owned smaller advertisements on electricity poles along the roads. In order to influence the competition between both companies, the government amended the law on road traffic and prohibited advertising on electricity poles and similar objects. ${ }^{33}$ However, the Prime Minister broke with said friend and competition was immediately restored. After another governmentfriendly oligarch purchased the ESMA, the law was changed again allowing to advertise on objects along the roads with permission. ${ }^{34}$ Further, a lex friend has been introduced, that may be applied flexibly to any friendly businesses if needed. A specific exception was added to the law on the prohibition of unfair commercial practices and of restriction of competition in 2013. The general rule prescribed that corporate mergers concerning companies whose annual turnover exceeded 15 billion HUF (47-48 million EUR) in total, were bound to take permission from the Competition Authority. The new exception rule made it possible for the government

\footnotetext{
${ }^{30}$ See e.g. decision no. 647/2018 of the National Election Office. The Office argued that basically, the 'information campaign of the government' should not be able to be confused with the campaign of the ruling party. However, in the concrete case, the massive anti-immigration 'government information' was not found to be such intervention to the election campaign-even if it happened only 8 days before the day of the election. The law was challenged before the Constitutional Court by opposition parties but the Court found no violation of the constitution. The Constitutional Court argued that the law in question did not regulate a cardinal subject because in fact, it did not change the normative content of the law on the functioning and management of parties. That law (Act XXXIII of 1989) is also cardinal and it sets up the elements of the asset of a party (§4). See AB decision no. 3001/2019. (I. 7.), ABH 2019, 35, especially para. 68 et seq.

${ }^{31}$ Art. VIII of the Basic Law, $\S 354$ of Act XXXVI of 2014 on the election procedure.

${ }^{32}$ The news portal Index collected many of them: https://index.hu/belfold/2012/06/04/lexek/. Beyond these examples, the so called 'lex Mocsai' is worth to be added. Namely Act XXXVI. of 2014 on the amendment of certain education laws prescribed (in its § 39) that Olympic medals count to be equal to an academic $\mathrm{PhD}$ in the higher education of sport: a month later, ex-trainer of the national water polo team, Lajos Mocsai became the rector of the University of Physical Education.

${ }^{33} \S 7$ (3b) of Act CXIX of 2012 on amending certain laws related to the traffic.

${ }^{34} \S 1$ of LXXXVII of 2015 on amending certain laws related to the traffic.
} 
to qualify certain mergers to be of strategical importance: such mergers do not have to be reviewed by the Competition Authority. ${ }^{35}$ Since then, this exception has been used several times: for the first time, in the same year, through a two-step privatisation of the biggest savings bank Takarékbank. ${ }^{36}$

In light of these examples, one thing becomes clear: these laws are targeted. Some have a wider, some have a narrower scope but the intention behind them is always the same: to punish the enemies or favour the friends of the government. Legislation designed to target individuals is not a new feature in the Hungarian legal system. ${ }^{37} \mathrm{~A}$ good example for this is the CEU itself which was recognised by a distinct law in 2004 by the then socialist government. ${ }^{38}$

Yet, individually designed legislation is always problematic because the rule of law requires laws to be general, applying to subjects in an undifferentiated manner. ${ }^{39}$ Therefore, it is questionable whether laws that genuinely apply only to a distinct scope of individuals, institutions or companies fulfil these essential requirements. Even more dangerous are laws, which pretend to have general effect but are designed in a way that they de facto apply only to a circumscribed circle of people. This is the common feature of the recent lex friends and lex enemies which became everyday practice of Hungarian politics. They became the 'silver bullets' for resolving almost any problem. This is one of the most important systemic rule of law problems in Hungary now-even if it has not been acknowledged by the EU institutions as a general pattern.

\subsection{Unrestrained Constitutional Amendments}

Even more alarming, however, are the developments at the constitutional level. The amendment of the constitution is relatively easy in the Hungarian unicameral parliamentary system: it simply requires the two-thirds majority of all MPs. ${ }^{40} \mathrm{With}$ regard to the Hungarian mixed election system, ${ }^{41}$ however, it was not expected that one single party could obtain such an overwhelming majority. In this sense, the two thirds majority requirement seemed to be a proper guarantee for political

\footnotetext{
${ }^{35} \S 24 / \mathrm{A}$ of Act LVII of 1996 on the prohibition of unfair commercial practices and of restriction of competition.

${ }^{36}$ The case was especially delicate because smaller savings banks were forced by law (Act no. CXXXV of 2013) to integrate into that Takarékbank, but their constitutional complaint against that law remained unsuccessful for the most part: see AB decision no. 20/2014 (VII. 3).

${ }^{37}$ In details Erdôs (2013), pp. 47-56.

${ }^{38}$ Act LXI. of 2004 on the recognition of the Central European University.

${ }^{39}$ Similarly Erdốs (2013), p. 55.

${ }^{40}$ Art. S of the Fundamental Law. The majority requirement has not changed with the new constitution, see $\S 24$ (3) of Act XX of 1949 on the constitution of the Republic of Hungary (in effect until 31. December 2011).

${ }^{41}$ About the half of MPs are elected in constituencies, and the other half from party lists.
} 
compromises. The situation changed in 2010 when-due to the scandalous governance of the socialists - the right-conservative Fidesz gained a two-thirds majority alone. After this victory, the Fidesz party did not feel obliged to prescribe stricter rules for amendments of the constitution.

To the contrary: the governing party used its overwhelming power for amending the constitution with controversial provisions several times. Some of these new provisions had even been annulled by the Constitutional Court previously. ${ }^{42}$ The probably most notorious of these amendments, was the Fourth Amendment to the Fundamental Law in April 2013. As a result of this amendment, the government implemented significant parts of the so called 'transitional provisions' to the Fundamental Law. These provisions had formerly been annulled by the Constitutional Court because they would have introduced some 'actually not transitional' provisions into the constitution. The Court had also pointed out that the 'transitional provisions' were neither parts of the constitution nor constitutional amendments: they were in the 'no men's land of public law'. 43

Further, the Fourth Amendment concerned topics like the possibility of levying taxes to finance obligations stemming from judgments of the Constitutional Court or of international courts, the National Judicial Office's president's right to reallocate cases, ${ }^{44}$ the introduction of the concept of 'dignity of communities' as a special limit to the freedom of speech, ${ }^{45}$ and the possibility of local governments to penalize homeless people if they live on the streets. ${ }^{46}$ Some of these laws had earlier-as ordinary legislation-been declared void by the Constitutional Court ${ }^{47}$ or were pending before the Court at that time. ${ }^{48}$ Further, point 5 of the closing provisions to the Fourth Amendment states: 'the decisions of the Constitutional Court taken prior to the entry into force of the Fundamental Law are repealed'. The reason for

\footnotetext{
${ }^{42}$ The first over constitutionalisation of the Fidesz government happened under the old constitution yet. After the Constitutional Court annulled the introduced $98 \%$ special tax on redundancy payments in the public sector, the Fidesz-majority amended the old constitution and explicitly allowed that and also limited the competences of the Constitutional Court in financial matters. See $\mathrm{AB}$ decision no 184/2010 (X. 28) (ABH 2010, 1161) and §§ 1-2 of Act CXIX of 2010 on the amendment of Act XX of 1949 on the Constitution of the Republic of Hungary. The rate of the tax was decreased to $75 \%$ at the end of 2013 , and after the third election victory resulting in two third majority, the Fidesz-majority of the parliament silently terminated this extra tax ( $\S \S 41-42$ of Act XLI of 2018 on the amendment of certain laws about taxation and on the immigration tax).

${ }^{43} \mathrm{AB}$ decision no. 45/2012 (XII. 29.), (Magyar Közlöny [Official Journal] 184/2012, p. 38979).

${ }^{44}$ These two provisions have been later abolished by the Fifth Amendment of the Fundamental Law in September 2013.

${ }^{45}$ Art. IX (5) of the Fundamental Law. Since then, the seventh amendment codified an explicit prohibition.

${ }^{46}$ Art. XXII (3) of the Fundamental Law.

${ }^{47}$ See e.g. AB decision no. 38/2012 (XI. 14.) (ABH 2012, 185) on the unconstitutionality of criminalising homelessness, $\mathrm{AB}$ decision no. 6/2013 (III. 1.) (ABH 2013, 194) on the unconstitutionality of the regulation of churches.

${ }^{48}$ See e.g. AB decision no. 36/2013 (XII. 5.) (ABH, 2013, 1045) on the 'case transfer' within the judiciary.
} 
this provision was that the Court often followed its former case law even after the Fundamental Law entered into force, at least in cases when the affected provision of the Fundamental Law and of the old constitution were the same or very similar. ${ }^{49}$ However the Court interpreted the newly amended closing provisions very creatively: it pointed out that point 5 of the closing provisions only gave the Court the opportunity, not to refer to its former decisions even if the affected rules and the context are the same. ${ }^{50}$

In order to overcome any restrictions and constitutional checks placed upon the government by the Constitutional Court, the Fidesz government established a strategy of 'over-constitutionalisation'. Namely, after the Court declared ordinary laws to be unconstitutional, the two-thirds majority simply 'solved the problem' by amending the respective provision of the constitution. Since the Constitutional Court cannot review the substance of constitutional amendments, ${ }^{51}$ constitutional checks and balances are in fact disabled. Further these constitutional amendments concern topics, which would normally be considered to be a matter of ordinary law. As such they lead to an inflated, trivialized constitutional law-to an 'overconstitutionalisation'. The consequences of this development for the Hungarian constitutional architecture are difficult to foresee.

Recently, this practice can be further illustrated with the seventh constitutional amendment. The Hungarian government has been a strict opponent of the EU migration policy and especially of the Council decision no. 2015/1601 on the relocation of 120,000 asylum applicants. While the government challenged this decision before the CJEU, the Hungarian Commissioner for Fundamental Rights initiated proceedings before the Hungarian Constitutional Court, practically requesting an ultra vires- and fundamental rights review. The motion was pending before the HCC when the Hungarian government decided to hold a referendum on the 'EU migrant quota system' (without an explicit legal basis). ${ }^{52}$ Since the turnout remained under $50 \%$, the referendum was legally invalid. ${ }^{53}$ In order to make it 'valid', the prime minister initiated a constitutional amendment in the autumn of 2016. Alongside the prohibition of settling 'foreign population' in Hungary, the amendment would have introduced an obligation for all state bodies to respect the constitutional identity of Hungary - without, however, defining this concept. This explicit reference to constitutional identity was obviously aimed at challenging the authority of EU law. Further, the constitution's EU-clause was intended to be

\footnotetext{
${ }^{49}$ See primarily AB decision no. 22/2012 (V. 11) (Magyar Közlöny [Official Journal, 52/2012, p. 9737), para. 40.

${ }^{50} \mathrm{AB}$ decision no. 13/2013 (VI. 17) (Magyar Közlöny [Official Journal], 98/2013, p. 54958), para. 31.

${ }^{51}$ See on this under Sect. 2.3.2.

${ }^{52}$ It makes no sense to hold a national referendum on an issue ruled by EU law: neither it is foreseen by the Hungarian constitution as it allows referendums only in questions which belong to the competence of the Hungarian National Assembly. See Art. 8 of the Hungarian Fundamental Law.

${ }^{53}$ According to Art. 8 (4) of the Fundamental Law, a referendum is valid if the number of valid votes exceed $50 \%$ of all citizens eligible to vote.
} 
amended so as to make the 'joint exercise of competences' subject to the fundamental rights and freedoms guaranteed by the Hungarian Fundamental Law and without limiting Hungary's sovereign right to command its population, territory and state order. ${ }^{54}$ Yet, this amendment failed because by that time the governing party did not hold the needed two-thirds majority anymore. After Fidesz regained a two-thirds majority in spring 2018, the seventh constitutional amendment ${ }^{55}$ was placed on the agenda again - this time with success. The amendment did not only provide for the constitutionality of the aforementioned 'Stop Soros' package on facilitating 'illegal migration'. ${ }^{56}$ It further concerned the law on the administrative courts, ${ }^{57}$ the new law on the freedom of assembly ${ }^{58}$ and the criminalisation of homelessness. Concerning the latter it not only established the possibility to ban habitual residence at public spaces by local governments' decrees ${ }^{59}$ but generally prohibits it at the constitutional level. ${ }^{60}$ In addition, the rules on the EU-clause and the reference to the obligation of all state bodies to respect constitutional identity have been codified at the

\footnotetext{
${ }^{54}$ Draft legislation no. T/12458. The text is available in Hungarian at the website of the National Assembly: www.parlament.hu/irom40/12458/12458.pdf.

${ }^{55}$ The consolidated version of the Fundamental Law after the seventh amendment is available in official English translation at: www.njt.hu/translated/doc/TheFundamentalLawofHungary_ 20181015_FIN.pdf.

${ }^{56}$ The new Art. XIV of the Fundamental Law now stipulates that foreign population cannot be settled in Hungary and the basic rules of granting asylum and asylum procedure must be defined by cardinal law. That means that an eventual future easing on the asylum rules will require a two thirds majority in the parliament. Further, it has been codified on the constitutional level that those who arrived through a safe third country, are not eligible to get asylum (this last point is codified also in the German Basic Law anyway: see Article 16a (2) GG). The 'Stop Soros' anti migration package was published in the official journal on the same day than the seventh constitutional amendment. See Act VI. of 2018 on the amendment of certain laws related to measures against illegal immigration.

${ }^{57}$ The constitutional amendment established the constitutional basis of a distinct system of administrative courts with the Administrative High Court on the top of it (new Article 25 of the Fundamental Law). See also Act CXXX of 2018 on the administrative courts. After the European elections of 2019, the government decided to delay the entering into force of this law for an indefinite period. The reason behind is most probably political: Fidesz still wants to stay in the European People's Party - where its membership has been suspended because of concerns over the rule-of-law-conformity of their governance-and therefore they made a gesture to show some willingness for a compromise.

${ }^{58} \mathrm{Art}$. VI of the Fundamental Law has been amended with a sentence with regard to the collision of privacy rights and of the freedom of expression and assembly. Namely, 'exercising the right to freedom of expression and assembly shall not impair the private and family life and home of others.' less than a month later, on the 20th of July 2018, the parliament adopted the new law on the freedom of assembly. The new law makes it possible to ban an assembly if it is likely to violate others' right to privacy and family, or to human dignity. ( $\$ 13$ (4) of Act LV of 2018 on the freedom of assembly.).

${ }^{59}$ As it had been the case since the fourth amendment which overruled AB decision no. 38/2012 (XI. 14.) (MK 2012/25417).

${ }^{60}$ Art. XXII (3) of the Fundamental Law as amended through the seventh amendment. In effect since 15. October 2018.
} 
constitutional level. ${ }^{61}$ This latter part of the amendment is especially interesting because it perfectly illustrates how the role and significance of the Constitutional Court has changed. Namely, through implementing these provisions into the constitution, an earlier decision of the Constitutional Court has not been overruled, but on the contrary, confirmed.

\subsection{The Constitutional Court: Still a Counterbalance or, Already an Ally of the Government?}

The significant event between the first attempt for the seventh constitutional amendment and its adoption in its final form was a judgment of the Constitutional Court. A few weeks after the planned constitutional amendment introducing the notion of constitutional identity in the constitution failed in autumn 2016, the Constitutional Court delivered a decision on the aforementioned motion of the Commissioner for Fundamental Rights concerning the Council decision on refugee-quotas. ${ }^{62}$ In that judgment, the Court established the possibility of an identity review of EU law (without being asked on such a review competence). Until then, the concept of constitutional identity had no significance in the case law of the Constitutional Court. ${ }^{63}$ The Court recycled the German case law on the matter, however in a rather selective way without clearly defining the content of this constitutional identity. ${ }^{64}$

The decision perfectly shows how the attitude of the Constitutional Court towards the government has changed in the last couple of years. Indeed, the case illustrates how the initial relationship between the Court and the government has been reversed: initially, the government tried to circumvent decisions of the court striking down ordinary laws through constitutional amendments. After the governing party lost its constitution-amending majority in the parliament, the Court presented itself as an institution compensating the government's lack of majority by constitutional interpretation. The Court substituted the requirement of two thirds majority through constitutional interpretation.

\footnotetext{
${ }^{61}$ New Art. E and the Preamble of the Fundamental Law as amended.

${ }^{62} \mathrm{AB}$ decision no. 22/2016 (XII. 5.) (ABH 2016, 1418).

${ }^{63}$ The concept occurred only once, in the parallel reasoning of (then constitutional judge, now justice minister) László Trócsányi to the Lisbon-decision (AB decision no. 143/2010 (VII. 14.), (ABH 2010, 872). Since then, the concept has only been referred by Fidesz-appointed constitutional judges at the Fide Congress in the spring of 2016 - when the motion of the ombudsman was already pending before the Court. See the speeches of András Zs. Varga and Tamás Sulyok at the XXVII. FIDE Congress. See Varga Zs (2016), pp. 9-10; Sulyok (2016), p. 40.

${ }^{64}$ There is only an illustrative list of the elements of constitutional identity in the decision with e.g. rights and freedoms, separation of powers, republican state form, parliamentarism, equality, protection of ethnic minorities. The rule of law is lacking from the list. AB decision no. 22/2016 supra note 62, para. 65. For a detailed critical analysis of the judgment see Bakó (2018), pp. 863-902.
} 
The push for the seventh amendment of the Fundamental Law shows, however, that the government still does not regard the Court as a 'trustworthy' ally. A portion of the seventh amendment secured the constitutionality of some reforms in the event that the Court's helpful attitude should change. On the other hand, the amendment, concerning the EU clause and the question of constitutional identity, illustrates the misgivings that the government still harbours regarding the Constitutional Court. Safe is only what is codified in the constitution-that is the general strategy of the Fidesz-government.

The changed relationship between the parliamentary majority and the Constitutional Court is easier to understand by analysing the changed composition and competences of the Court and the new strategies applied by the Court in its everyday practice.

\subsubsection{Filling the Court with Fidesz-Loyalist Judges}

Constitutional judges are elected with two thirds majority of the parliament. This has not changed since 1990 . However, prior to 2010 , candidates used to be proposed by a parity-based committee comprising of all parliamentary groups. Therefore, even if a government had a supermajority in the parliament, a compromise with the opposition would have been required concerning the candidates.

In July 2010, Fidesz with their supermajority amended the old constitution to ensure that the composition of the committee represents the power relations in the parliament. ${ }^{65}$ Since then, no compromise has been needed—at least as long as the governing parties had a supermajority. In September 2011, the number of the constitutional judges was raised from eleven to fifteen and their mandate was extended from 9 to 12 years. ${ }^{66}$ Between 2010 and 2013, eight constitutional judges had been appointed exclusively with the votes of the Fidesz. By spring 2013, Fideszappointed judges had a majority in the Court. In autumn 2014, three further judges were elected by the Fidesz-MPs. ${ }^{67}$ While Fidesz temporarily lost its two-third majority in February 2015, the term of some judges expired. In order to not jeopardize the Court's pro-Fidesz attitude by electing judges of a different political orientation, the Court was left to operate with 11 judges instead of 15 for months and the election of new constitutional judges was not even put on the agenda of parliament for some time. Finally, in autumn 2016, the parliament elected four

\footnotetext{
${ }^{65} \S 32 / \mathrm{A}(5)$ of the old constitution as amended on the 5th of July 2010.

${ }^{66}$ Act LXI of 2011 on the amendment to the (old) constitution, § 3; Act LXII. of 2011 on the amendment to the (old) Act on the Constitutional Court (Act XXXII. of 1989), § 1 (2). New Fundamental Law Art. 24 (8) and the new Act on the Constitutional Court (Act CLI of 2011), § 6 (3) - both have been in force since 1. January 2012.

${ }^{67}$ In his empirical analysis focusing on the period between 2010 and 2014, Zoltán Szente pointed out that the level of political adaptation of the majority of the constitutional judges was surprisingly high. In details see Szente (2016), p. 66.
} 
new judges with the support of the green party. However, this could not significantly change the balance and the attitude of the Court.

\subsubsection{Limiting Constitutional Review in Important Cases}

Concerning the powers of the Court, two problematic points must be emphasized. First, substantive review of constitutional amendments has been explicitly excluded. ${ }^{68}$ Neither the old constitution nor the original version of the new Fundamental Law contained any reference to the substantive review of constitutional amendments. Yet the Constitutional Court generally considered itself not competent for such a review. ${ }^{69}$ From 2011 on, it has happened several times that constitutional amendments have been introduced to incorporate provisions that had been formerly invalidated by the Constitutional Court. As described above, ${ }^{70}$ the government acting through parliamentary supermajority amended the constitution incorporating several provisions that were previously declared invalid. While the Constitutional Court theoretically had the chance to take an activist step by changing its former case law and review constitutional amendments on their substance, the Fourth Amendment erased the Court's discretion in this regard. The Fourth Amendment of the Fundamental Law explicitly prohibits the Constitutional Court to substantially review constitutional amendments by limiting judicial review of constitutional amendments to procedural aspects alone. ${ }^{71}$ Absent any other constitutional guarantees limiting the amending power of the parliament, these constraints placed on the Constitutional Court raise substantial concerns. Since constitutional amendments are also excluded subjects for referendums, ${ }^{72}$ neither the Constitutional Court nor the people have any direct control over how the two thirds majority in parliament amends the constitution.

Second the new Fundamental Law restricted the competence of the Constitutional Court regarding the review of acts concerning public revenue and expenditure. Until the state debt exceeds $50 \%$ of the GDP, the Constitutional Court may review the Act

\footnotetext{
${ }^{68}$ Art. 24 (5) of the constitution stipulates: 'The Constitutional Court may review the Fundamental Law or the amendment of the Fundamental Law only in relation to the procedural requirements laid down in the Fundamental Law for making and promulgating it.' (My italics).

${ }^{69}$ For details see e.g. Jakab and Szente (2009), para 117; Bakó (2017), pp. 105-108.

${ }^{70}$ See Sect. 2.2.

${ }^{71}$ See the present Art. 24 (5) of the Fundamental Law. The Commissioner for Fundamental Rights made a motion against the Fourth Amendment, arguing that the amendment caused inner contradictions within the constitution. However, the Court declared its lacking competence for the review of the constitutional amendment, referring to the terms of the constitution as amended through the amendment subject to that review, see AB decision no. 12/2013 (V. 24.) (ABH 2013, 390).

${ }^{72}$ Holding a referendum about constitutional questions is now explicitly excluded by Art. 8 of the Fundamental Law: under the old constitution, it was an unwritten taboo, established and consequently reaffirmed by the Constitutional Court. See primarily AB decisions no. 2/1993 (I. 22.) and 25/1999 (VII. 7.).
} 
on State Budget and other acts related to public finances only if they violate human dignity or other enumerated fundamental rights. ${ }^{73}$ Some authors consider this rule to be a 'dishearteningly materialistic reading of constitutionalism' as it practically means the suspension of the rule of law until a certain debt is reached ${ }^{74}$ implying that the constitution is not necessarily the highest law anymore. ${ }^{75}$ On a theoretical level, such criticism is right and well founded, especially taking into account the circumstances. The taboo of reviewing financial laws has been a part of the strategy of 'over-constitutionalisation', described above. After the Constitutional Court struck down a law that levied a $98 \%$ tax on certain severance payments in the public service, ${ }^{76}$ the old constitution was amended in order to allow levying special taxes on remunerations 'received against the good morals' retroactively. ${ }^{77}$ Further, the aforementioned limitation of the Constitutional Court's competences concerning laws related to the central budget, was introduced. ${ }^{78}$ Following this new restriction, constitutional complaints in financial and economic matters have mostly been rejected in their entirety or to a large extent. ${ }^{79}$ However, these complaints were not necessarily rejected on the grounds of lack of jurisdiction but because the respective limitations of fundamental rights were not unnecessary and disproportional. ${ }^{80}$

\subsubsection{New Strategies of the Constitutional Court: Shifting Away from the Control of the Legislative}

In light of the changes to the competences and composition of the Court, a crucial question relates to if and how the attitude of the institution has evolved. Although

\footnotetext{
${ }^{73}$ Art. 37 (4) of the Fundamental Law. The state debt was $77.6 \%$ of the GDP at the beginning of 2012 - as the Fundamental law entered into force. According to the last data of the Hungarian Central Statistical Office, the debt was $73.3 \%$ in 2017 (http://www.ksh.hu/docs/hun/xftp/stattukor/ edp/edp181024.pdf). So, this restriction probably will remain in place for a while.

${ }^{74}$ Vincze and Varju (2012), p. 451.

${ }^{75}$ Halmai (2012), p. 1082.

${ }^{76} \mathrm{AB}$ decision no. 184/2010. (X. 28), ABH 2010, 1161.

${ }^{77} \S 70 / \mathrm{I}(2)$ of the old constitution as amended. At the same time it must be seen, especially in the EU-context, that national constitutional courts and the effectiveness of national constitutional principles are often limited by EU-law and by measures of EU institutions in the field of financial legislation. See the OMT case (BVerfG, 2 BvR 2728/13, OMT and CJEU, Case C-62/14 Gauweiler, ECLI:EU:C:2015:400) and the PSPP case (BVerfG, 2 BvR 859/15, PSPP and CJEU, Case C-493/ 17 Weiss, ECLI:EU:C:2018:1000).

${ }^{78}$ In details see e.g. Sonnevend et al. (2015), pp. 94-95.

${ }^{79}$ Gárdos-Orosz (2016), p. 444.

${ }^{80}$ See e.g. AB decision no. 20/2014 (VII. 3.) (MK 91/2014, 10918) regarding the integration of cooperative banks and AB decision no. 3194/2014 (VII. 15.) (ABH 20/2014, 991) regarding the commerce of tobacco products. For an overview of the Constitutional Court's case law on budgetary matters see Tilk (2014).
} 
there are some positive examples in the Court's latest case law related to fundamental rights ${ }^{81}$ and the rule of law, ${ }^{82}$ two relevant tendencies can be identified.

First, the Court has distanced itself from politically relevant questions. As the abstract norm control has been subsequently displaced by concrete forms of judicial review, primarily by the newly established constitutional complaint, the focus has shifted from the constitutional review of legislation towards the constitutional review of the application of the law. ${ }^{83}$ Thus, the role of the Constitutional Court in the system of checks and balances has changed profoundly. ${ }^{84}$ The Court is no real counterweight to the parliament anymore. A recent example is the judgment on the penalisation of homelessness, established by the seventh amendment to the constitution. Finding first that the newly introduced offence was constitutionally valid, the Court established a constitutional requirement for the practical application of the relevant paragraph. In order to comply with the aim of this constitutional prohibition, respectively the integration of homeless people into the social care system, $\S 178 / \mathrm{B}$ of the Act on Offences may only be applied if the affected person can be provided with accommodation at the time the offence was committed. ${ }^{85}$ However, the Court did not even discuss the question of whether the penalisation itself was a proportional tool for the implementation of the constitutional prohibition. The Court decided to avoid any conflict with parliament by annulling the law. Instead, it left the law in force and only modified its interpretation in light of constitutional requirements.

Second, even when the Court adjudicates on the validly of a piece of legislation and finds it to be contrary to the constitution, it has been cautious to strike it down and applied a more lenient approach. ${ }^{86}$ Instead of annulling a law, it often prescribes constitutional requirements for the law's interpretation by ordinary courts. This happens even in politically significant matters or cases concerning fundamental rights. ${ }^{87}$ Further, the timing of the decisions (in relation to politically important events, like referendums or elections) might also have significant impact (see e.g. the constitutional identity decision discussed above).

\footnotetext{
${ }^{81}$ In December 2017, the Court ruled that it is an obligation for the parliament to decide on the status on churches within a reasonable time and ordered the legislator to establish proper guarantees in order to keep the 60 days deadline. See decision no 36/2017. (XII. 29.), ABH 2018, 2. Another recent case concerned media freedom: a CC judgment delivered at the end of 2017 made clear that a medium is not liable for the violation of personality rights if it was covering a press conference. $\mathrm{AB}$ decision no. 34/2017. (XII. 11.), ABH 2017, 2058.

${ }^{82}$ The Constitutional Court annulled some parts of an order of the president of the National Judicial Office because it foresaw unconstitutional sanctions against judges, moreover, without the right of appeal. AB decision no. 33/2017. (XII. 6.), ABH 2017, 2031.

${ }^{83}$ For empirical data see Gárdos-Orosz (2016), pp. 448-452.

${ }^{84}$ Orbán (2016), pp. 7-9.

${ }^{85} \mathrm{AB}$ decision no. 19/2019 (VI. 18.), ABH 2019, 1052, paras. 105-110.

${ }^{86}$ Gárdos-Orosz (2016), p. 449.

${ }^{87}$ Id. See also Halmai (2015), p. 146.
} 
Finally, many sensitive cases are still pending before the Court—like the NGO law and the 'lex CEU', which are both subject to an infringement procedure and therefore (questionably) suspended by the Constitutional Court with the probable motivation of avoiding any conflict with the government. ${ }^{88}$

\section{Why Infringement Procedures Are Ineffective in the Case of Hungary}

Currently, the only judicial tool of enforcing EU values compliance is the infringement action. However, this procedure is intended to enforce compliance with EU law concerning rather specific matters, instead of addressing systemic rule of law deficiencies. This problem is also illustrated by the infringement actions launched against Hungary in the past few years related to EU values. Although Hungary did de facto not comply with the CJEU's decisions in some of the cases, the respective issues were regarded as solved. In this section, I will briefly discuss the infringement proceedings regarding some of the above-mentioned targeted laws. It is important to recall that 'rule of law' deficiencies in Hungary arise from the whole gamut of constitutional malfunctions on one hand and the system of targeted legislation on the other. Therefore, individual infringement procedures against some selected pieces of targeted legislation cannot solve the problem, even if the Hungarian government fully complies with the decisions of the CJEU.

\subsection{CJEU Judgments Being Fully or Partly Ignored}

In the case concerning the premature termination of the data protection ombudsman's term of office, the European Commission initiated an infringement procedure based on a violation of the Data Protection Directive (95/46/EC). The Hungarian government argued that the directive required independence in an operational sense ${ }^{89}$ which had not been violated by the personal and institutional changes.

The CJEU delivered its decision in April 2014 dismissing Hungary's plea. According to the Court, the threat of a premature termination of the term of office 'could lead it to enter into a form of prior compliance with the political authority, which is incompatible with the requirement of independence' ${ }^{90}$ It stated that merely preserving the operational independence of the president of the new Data Protection

\footnotetext{
${ }^{88}$ See Sect. 2.1.4 above.

${ }^{89} 95 / 46 / \mathrm{EC}$ directive, Art. 28 (1).

${ }^{90} \mathrm{CJEU}$, Case C-288/12 Commission v. Hungary, ECLI:EU:C:2014:237, para. 54.
} 
Authority was not enough ${ }^{91}$ and the reorganisation of the institutional framework was not sufficient ground for the termination of the ombudsman's term without applying proper transitional measures. ${ }^{92}$ The status of the Data Protection Authority has not been changed since the judgment.

Regarding the new retirement rules applying to judges, the government has shown some readiness for compromise and recommended raising the retirement age to 65 from the originally intended 62 . The Commission did not accept that and initiated an accelerated infringement procedure.

Simultaneously, the Hungarian Constitutional Court also examined the question and ruled in July 2012 that the regulation was violative of judicial independence and thus unconstitutional. The Hungarian Constitutional Court knew that a parallel infringement procedure was in progress. As such, the Constitutional Court could challenge the government without taking any risk $^{93}$ and voided the law retroactively. ${ }^{94}$

The decision of the CJEU in the infringement procedure, delivered 4 months later examined the case as pertaining to a question of discrimination under Directive 2000/78. The CJEU ruled that the Hungarian regulation violated the directive ${ }^{95}$ without, however, basing its decision on the requirement of judicial independence. ${ }^{96}$

Following these rulings, the laws on the status of judges (and of prosecutors and notaries too) have been amended: affected judges had to choose whether they wanted to retire or continue assuming their office. Such decisions were also motivated by a legal amendment according to which those judges who do not want to return to service were eligible to compensation in the amount of 12 months remuneration. ${ }^{97}$

\footnotetext{
${ }^{91}$ Id., para. 51.

${ }^{92}$ Id., para. 61.

${ }^{93}$ For a comparative analysis of the judgments of the CJEU and of the Hungarian Constitutional Court, see Vincze (2013), pp. 330-333. Of course, normally, a constitutional court would not have to take any risk in cases like that but in Hungary, the government's recent practice shows that it is likely to amend the constitution with the content of laws which has been just annulled by the Constitutional Court.

${ }^{94} \mathrm{AB}$ decision no. 33/2012. (VII. 17) (MK [official journal] 2012, 13918). The meanwhile retired judges did not get back to office automatically, but they had to claim an action before the Labour Court - many of them decided rather not to do that.

${ }^{95} \mathrm{CJEU}$, Case C-286/12 Commission v. Hungary, ECLI:EU:C:2012:687. The Court did not take into account that the Hungarian Constitutional Court meanwhile annulled the provisions in question because that happened after the start of the infringement procedure.

${ }^{96}$ Interestingly, the case law of the CJEU had changed significantly within a couple of years. In the very similar case of sending Polish Supreme Court judges into retirement, the CJEU's dismissing judgment, delivered in June 2019, was primarily based on the principle of judicial independence and to Art. 19 (1) TEU. CJEU, C-619/18 Commission v. Poland, ECLI:EU:C:2019:531, paras. 96, 124.

${ }^{97} \S 323 / \mathrm{I}(6)$ of Act XX of 2013 on certain legal amendments related to the age limit in certain positions in the justice system.
} 
Thus, many judges were not reinstated into their former, leading positions. ${ }^{98}$ Further, they must still retire by reaching the general retirement age of 65 years. ${ }^{99}$ To sum up, the initial situation has not fully been restored. Further, other threats to judicial independence, like the controversial appointment practice of the president of the National Judicial Office, ${ }^{100}$ have not even been addressed by infringement procedures. $^{101}$

\subsection{Infringement Cases Regarding the NGO Law and the Lex CEU}

In parallel to the procedure before the Hungarian Constitutional Court, the European Commission launched an infringement procedure concerning the NGO law. The ECJ ruled in June 2020 that the law represented unjustified restrictions to the free movement of capital and to the right to privacy, data protection and the freedom of association as guaranteed by the EU Charter of Fundamental Rights. ${ }^{102}$

Further, the 'Stop Soros package' has been subject to an infringement procedure since July 2018. The procedure is based on a twofold argument. First, the Commission criticises the non-compliance with the Asylum Procedures Directive, the Asylum Qualifications Directive and the Reception Conditions Directive by criminalising the support for asylum applications and by introducing a new non-admissibility ground. ${ }^{103}$ Second, the Commission challenges the injunction to stay away from the border, arguing that the respective legal provision is contrary to the TFEU, the Charter and the Free Movement Directive because it 'unduly restricts the exercise of free movement rights of EU citizens without due regard for procedural guarantees.' In September 2018, the Hungarian government refused to make any changes to the package. ${ }^{104}$

\footnotetext{
${ }^{98}$ This was also the subject of a complaint of more than 150 judges before the ECtHR. The Strasbourg Court finally dismissed the complaints. In the appendix of the judgment it is apparent that the majority of the applicants accepted the lump-sum compensation for not being reinstated. See $J$. B. and others v. Hungary, ECtHR case no. 45434/12.

${ }^{99}$ See the new $\S 91$ of Act CLXII of 2011 on the Legal Status and Remuneration of Judges (following Act XX of 2013 on amendments regarding the retirement age in certain jurisdictional position).

${ }^{100}$ See Vadász (2018). Meanwhile, the practice of the NJO president has been subject to a preliminary reference, see CJEU, Case C-564/19, IS.

${ }^{101}$ The problem, that systemic deficiencies of the independence of the judiciary, are not holistically handled by the CJEU, occurred more clearly in the case of Poland. See e.g. opinion of AG Tanchev in Joined Cases C-585/18, C-624/18 and C-625/18, A.K., para. 147.

${ }^{102}$ Judgment in case no. C-78/18, para 143. ECLI:EU:C:2020:476

${ }^{103}$ See press release no. IP/18/4522.

${ }^{104}$ A kormány válasza az Európai Bizottságnak: marad a Stop Soros [The government's answer to the European Commission: Stop Soros remains] http://www.kormany.hu/hu/igazsagugyi-
} 
Concurrently, affected NGOs launched constitutional complaints before the Hungarian Constitutional Court arguing that the introduction of the new offence of 'facilitating illegal migration' unconstitutionally restricted the freedom of association and the freedom of expression. One of these complaints has already been rejected. Nevertheless, the Court seemed to have a rather open attitude towards the case. First, the complaint was not submitted by an affected person (but by an organisation with a more abstract relationship to the contested provision) and without exhausting the ordinary remedies beforehand. ${ }^{105}$ Instead of dismissing the case as inadmissible, however, the Court referred to an exceptional rule of the Act on the Constitutional Court ${ }^{106}$ and to the HCC's function as a protector of fundamental rights ${ }^{107}$ and examined (and eventually rejected the case) on the merits.

Finally, the 'lex CEU' is by far the most problematic case. Generally, education is a Member States' competence. The Commission based its charges on the freedom of establishment and the freedom to provide services with reference to universities from third countries. The applicability of EU law, however, is highly questionable in this case considering that only universities with links to third countries are affected. ${ }^{108}$ Due to the lack of any intra-EU cross-border element, this argument presupposes an extensive interpretation of the freedom of establishment clause: an understanding similar to that adopted in Ruiz Zambrano. ${ }^{109}$ However, unlike the applicants in the Zambrano case, the CEU is a legal person and thus could not rely on the 'substance' of Union citizenship under Article 20 TEU. Therefore, the Commission's reference to academic freedom, freedom of education and freedom to conduct a business as guaranteed by the EU Charter of Fundamental Rights raises the question: how can the scope of EU law in the sense of Article 51 (1) of the Charter be triggered? A way to circumvent these problems happened to be WTO law. The CJEU, contrary to its former case law, applied WTO law directly in the case and ruled that Hungary failed to comply with its commitments under the GATS convention and this equals to the failing to fulfil its obligations under EU law. The fact that this convention was an integral part of EU law was found to be enough reason also for the application of the Charter. ${ }^{110}$

miniszterium/parlamenti-allamtitkarsag/hirek/a-kormany-valasza-az-europai-bizottsagnak-marada-stop-soros.

${ }^{105}$ See $\S \S 26-27$ of Act CLI of 2011 on the Constitutional Court about the requirements of submitting a constitutional complaint.

${ }^{106} \S 26$ (2) of Act CLI of 2011 on the Constitutional Court regulates the exceptional requirements when constitutional complaints are acceptable also beyond the general conditions. These include cases when the threat of fundamental rights violation is direct and does not require a judicial decision and cases when no remedies are provided. In the case of the amendment of the Criminal Code, neither requirement is fulfilled, so by accepting the complaint, the Constitutional Court obviously made an activist step in the field of individual fundamental rights protection.

${ }^{107}$ AB decision no. 3/2019 (III. 7.), Magyar Közlöny [official journal] 2019, 912, paras. 32-42.

${ }^{108}$ See press release no. IP/17/1952 and MEMO/17/3494.

${ }^{109}$ See e.g. the Zambrano judgment: C-34/09, ECLI:EU:C:2011:124.

${ }^{110}$ Judgment in case no. C-66/18, especially paras 86-93. and 212-215. ECLI:EU:C:2020:792. 
The amendment of the Higher Education Law—or, the 'lex CEU' as it is often referred to-is much easier to be challenged under Hungarian constitutional law than under EU law. Unlike the Charter provisions, the academic freedom and freedom of education as guaranteed by the Hungarian constitution undoubtedly apply to the act in question. Further, the legislation arguably violates the principle of the rule of law as guaranteed in Article B) (1) of the Fundamental Law: not only through the tight-although later extended—vacatio legis, but also by posing a threat to legal certainty and legitimate expectations. Further, by requiring prior consent of the federal government for agreements with federal states, the law demands the legally impossible. ${ }^{111}$ Additionally, if an international agreement is a prerequisite for the further functioning of an accredited university, it practically means that the exercise of academic freedom 'depends on the political discretion of two sovereigns'. ${ }^{112}$ This is very problematic regarding both fundamental rights and the rule of law.

Yet the Hungarian Constitutional Court suspended the review of the lex CEU with reference to the pending cases before the CJEU. The strategy of the HCC was probably the following: waiting for the decision of the CJEU and hoping that the lex CEU will get the green light under EU law. That would have been a win-win situation for the HCC: it would have been able to reaffirm the constitutionality of the law and avoid any conflict with the CJEU or the government. The strategy did not work, the CJEU dismissed Hungary. The aforementioned infringement proceedings were directed against specific pieces of targeted legislation, without embedding them in the broader context and evaluating the general practice of personalised legislation. The fact, that 'ordinary' infringement procedures are not suitable to address systemic patterns, has been pointed out by legal scholarship long ago. ${ }^{113}$ Yet, the respective proposals have not been implemented in EU legislation or practice.

\footnotetext{
${ }^{111}$ In detail see the amicus curiae brief of András Jakab, Miklós Lévay, László Sólyom and Zoltán Szente to the Constitutional Court (case no. II/01036/2017). It has to be added that this impossible requirement has already been ignored by the Hungarian Government itself by closing such an agreement with the state of Maryland. See the Agreement between the government of Hungary and the state of Maryland and on cooperation in the field of higher education as promulgated by Act CXIV. of 2017. The agreement provides the further functioning of the McDaniel College in Budapest under the new legal framework. In the agreement, there is no reference to any prior consent of the US federal government.

${ }^{112}$ Uitz (2017).

${ }^{113}$ Scheppele (2013a) and Bárd and Śledzińska-Simon (2019).
} 


\section{Making a Try with Article 7: The Sargentini Report on Hungary}

As seen above, the infringement procedure as currently operated by the Commission is insufficient for addressing the systemic key issues in Hungary. The following section will analyse whether procedures in the political realm are more apt to challenge the Hungarian rule of law deficiencies.

The first comprehensive political document on the new Hungarian constitutional system and its compatibility with EU values was adopted as early as June 2013: this was the non-binding EP resolution named after its rapporteur Tavares. ${ }^{114}$ The report criticised the media situation, ${ }^{115}$ the legislation concerning the judiciary and the Constitutional Court, ${ }^{116}$ some fundamental rights issues, especially the rules of the recognition of churches, ${ }^{117}$ the reform of the election system ${ }^{118}$ and not least, the practice of amending the Fundamental Law systematically along political interests, with special regard to its Fourth Amendment. ${ }^{119}$ As a reaction to the Tavares report, the Fundamental Law has been amended for the fifth time in September 2013. Some points of criticism have been slightly modified or suspended (like the case transfer within the judiciary or, the possibility of levying special taxes to finance obligations stemming from decisions of the $\mathrm{HCC}$ or of international courts). Yet, the main

\footnotetext{
${ }^{114}$ EP report no. P7_TA(2013)0315.

${ }^{115}$ The most criticised point was the independence of the Media Authority. However, it has been proven in the last years that the media problem is not of an institutional kind. It is rather about the fact that government friendly investors purchase even more formerly independent media platforms and turn them to be loyal to the government or even propagandistic (or they just simply close them, as it happened to the biggest daily newspaper called Népszabadság in October 2016). In detail, see e.g. Bátorfy (2017), pp. 12-13.

${ }^{116}$ See Sects. 2.1.2 and 2.3.2 above on these matters.

${ }^{117}$ The Constitutional Court annulled some earlier versions of the law on churches: $\mathrm{AB}$ decisions no 164/2011 (XII. 20) (ABH 2011, 1263) and 6/2013 (II. 26.) (ABH 2013, 334). In its later decisions, it called the government more times for amending the relevant laws, see AB decisions no. 23/2015 (VII. 7.) (ABH 2015, 1043), 36/2017 (XII. 29) (ABH 2018, 2). The ECtHR also dismissed Hungary upon the issue (Magyar Keresztény Mennonita Egyház and others v. Hungary, Application Nos. 70945/11 23611/12, 26998/12 et al.). The rules have been changed quite often meanwhile, most recently in November 2018. The basic idea is however the same: there are different categories of churches, and they are recognised by the parliament. Pursuant to the latest amendment, the recognition by the parliament only applies to 'settled churches' while other religious communities will be registered by courts (see Act CXXXII of 2018 on the amendment of Act CCVI of 2011 on the freedom of religion and on the status of churches and other religious communities, especially the new $\S \S 9 / \mathrm{A}-9 / \mathrm{G})$.

${ }^{118}$ The new election law (Act CCIII of 2011 on the election of the members of parliament) basically upholds the former mixed system but it has been complemented with a tricky gerrymandering and some unfair rules for the campaign (Section VIII of Act. XXXVI. of 2013 on the election procedure).

${ }^{119}$ More details in Sect. 2.2 above.
} 
problematic points remained in place and the rule of law in Hungary has not improved through this amendment. ${ }^{120}$

\subsection{Getting Lost in Details, Missing the Bigger Picture}

Unfortunately, very little of the deficiencies discussed above were addressed by the Sargentini report adopted in September 2018. This second comprehensive EP resolution on the situation in Hungary triggered an Article 7 TEU procedure ${ }^{121}$ and concentrated on 12 issues related mainly to fundamental rights protection ${ }^{122}$ and the rule of law. ${ }^{123}$ Although the report mentions many relevant deficiencies, it gets lost in irrelevant details and misses the bigger picture.

To name just but a few examples: concerning the Constitutional Court, the Data Protection Authority and judicial independence, mostly the findings of the Tavares report remain repetitive without analysing the recent developments in these fields (points 8-9, 12-18). Related to fundamental rights, the report echoes some partly unfounded criticism concerning the alleged oppression of Roma, Jewish minorities or women (points 59-61, 46). ${ }^{124}$ Further issues included in the report relate to media freedom (points 27-30), the secret surveillance for national security purposes without sufficient legal guarantees (points 25-26), the penalization of homelessness (point 73 ), and violations of the academic freedom, the freedom of assembly and the freedom of expression (points 33-36, 41-45). Furthermore, a new topic took centre stage: corruption. On the one hand, the report correctly mentions cases where OLAF found serious irregularities and possible fraudulent activities related to the spending of EU funds, some of them share links to the family of the prime minister (point 23). ${ }^{125}$ On the other hand, the report also discusses irrelevant technical details like MPs asset declarations or the system of campaign financing (points 20-21).

\footnotetext{
${ }^{120}$ Similarly, Szente (2017), p. 470.

${ }^{121}$ European Parliament resolution of 12 September 2018 on a proposal calling on the Council to determine, pursuant to Article 7(1) of the Treaty on European Union, the existence of a clear risk of a serious breach by Hungary of the values on which the Union is founded (2017/2131(INL)).

${ }^{122}$ Freedom of expression, freedom of association, academic freedom, freedom of religion, privacy and data protection, the right to equal treatment, social rights, rights of asylum seekers.

${ }^{123}$ Functioning of the constitutional system, the independence of the judiciary, corruption.

${ }^{124}$ The most striking false statement is that the Criminal Code does not fully protect women who have been victims of domestic violence (point 46). Actually, a new offense has been introduced already during the governance of the Fidesz, exactly in order to address this problem. See 212/A. § of Act C of 2012 on the Criminal Code.

${ }^{125}$ The company of the son-in-law of the prime minister won public procurement procedures in several towns and villages for the modernisation of street lightings. Many of the procurement tenders were directly designed exactly and exclusively for his company. The Hungarian authorities started an investigation but it was finally cancelled in November 2018. (Hungarian investigative portal Átlátszó wrote about the story in details: https://atlatszo.hu/category/cikkek/eliosaktak/.) It is
} 
Eventually, the report does the Hungarian government a huge favour when dealing exhaustively with Fidesz's old-time campaign topic-migration. Yet even here the report misses the crucial point: the introduction and emphasis by the government on the 'crisis situation caused by mass migration'. This new state of emergency enables the government to apply less guarantees during the asylum application procedures in order to significantly accelerate them. ${ }^{126}$ The crisis situation has constantly been prolonged since 2015 , even if the legal requirements are clearly not fulfilled. ${ }^{127}$ Instead of identifying this obvious and systemic rule of law deficiency, the report rather concentrates on recording statistical data on the detention circumstances and the frequent refusal of appeals (points 62-72). Moreover, by criticising a judgment in a specific criminal case, the report makes the impression of intervening into that case, ${ }^{128}$ which is highly questionable with regard to the rule of law itself.

In sum, proper grounds could be found for launching an Article 7 procedure against Hungary, but only a few of them have been identified. And even those elements that have been identified, are not convincingly placed within the system of constitutional malfunctions. The report failed to realise the patterns: neither the tendency of targeted legislation, nor the logic of "over-constitutionalisation" behind some constitutional amendments were identified. Further, relevant arguments are diluted with rather strange and minor, sometimes unfounded allegations: ${ }^{129}$ this feeds such counterarguments that portray the report as a purely politically motivated attack. Based on such an ill-founded report, Article 7 will surely remain a tool of political cherry picking, failing to play a serious role in safeguarding the rule of law.

\subsection{Limited Political Relevance}

Despite several shortcomings of the Sargentini report, the Hungarian government decided not to go into a substantial debate on the rule of law or fundamental rights. Instead, the government challenged the report on formal grounds arguing that the

worth to recall at this point that the Prosecutor General was elected by the two thirds majority of the parliament and actually, he is an ex-Fidesz member and an old friend of the Prime Minister.

${ }^{126} \S \S 80 / I-J-K$ of Act LXXX of 2007 on asylum.

${ }^{127}$ Such crisis situation may be announced basically if more than 500 applicants arrive daily in the average of at least a month. This is not the case for a long time according to the statistics, but there is a more flexible rule too- namely, the threatening of the public order in any Hungarian municipality (not necessarily closed to the border). The interpretation and application of this flexible provision belongs to the discretion of the government. See 80/A § of Act LXXX of 2007 on asylum.

${ }^{128}$ That is the case Ahmed $\mathrm{H}$, who has been condemned for 5 years imprisonment because of an 'act of terror' by the Hungarian courts following a riot at the boarder to Serbia. See Article 67 of the report. In January, 2019 he was ordered to be expelled from Hungary.

${ }^{129}$ For example the oppression of LGBT, Jewish or Roma minorities and the lacking protection of women from domestic violence etc. 
two thirds majority requirement for the EP voting was not fulfilled because abstentions were not counted as votes cast. ${ }^{130}$ After referring to these procedural defects and declaring the Sargentini report as void, there seems to be no place for stepping back and finding compromises. As such, the Sargentini report was an ideal target for the Hungarian government in the campaign before the EP-election of 2019. Fidesz called the Hungarian voters to resist pro-migration EU bureaucrats 'punishing their own border guards': $52.56 \%$ of them did so by voting for the Fidesz.

More than two years have passed since the EP adopted the Sargentini report, but the Council still has not made any decision. Only some hearings took place over 2019. This is not a surprise as a similar inertia can be observed with regard to Poland. Nevertheless, rapporteur Sargentini has been eager to keep the issue of Hungary on the agenda of the LIBE committee and to pressure the Romanian Council presidency to table the case during the first half of 2019. In light of the fact that serious concerns have been raised concerning the rule of law in Romania, ${ }^{131}$ it is no surprise that the Romanian Council presidency did not hurry up with the Article 7 processes either against Hungary or Poland. It is worth recalling that the Hungarian and Polish governments promised to veto any steps against each-other in the Article 7 procedure.

\section{How to Take 'Informed' Measures in Defence of the Union's Values?}

Until here, I have tried to illustrate the complexity of the Hungarian developments and also show how insufficient the different processes launched by EU institutions have been. If values are codified normatively_as they are in Article 2 TEU-and rule of law is to be taken seriously, there should be an objective and transparent tool to "measure the unmeasurable". ${ }^{132}$ As such, it comes as no surprise that the idea of measuring the rule of law is a matter of increasing importance within the EU institutions nowadays. In this last section, I will briefly outline some recent proposals and point out the difficulties of using indicators to detect systemic rule of law problems.

\footnotetext{
${ }^{130}$ CJEU, Case C-650/18, Hungary v. Parliament (pending). The legal situation is not obvious at this point. The Rules of Procedure reads that 'in calculating whether a text has been adopted or rejected, account shall be taken only of votes cast for and against, except in those cases for which the Treaties lay down a specific majority' (Rule 178 (3) RoP). So the question is whether the two thirds majority required by Article 354 (4) TFEU counts as a 'specific majority'.

${ }^{131}$ See EP resolution no. P8_TA(2018)0446.

${ }^{132}$ Cf. Schmitt (1996), p. 3.
} 


\subsection{Measuring, Buying or Monitoring the Rule of Law?}

In October 2016 the European Parliament made a proposal to the Commission ${ }^{133}$ to introduce an Interinstitutional Agreement-the European Union Pact on Democracy, the Rule of Law, and Fundamental Rights (DRF Pact). It seemed to be inspired by an earlier academic debate on the 'Copenhagen dilemma' and especially by Jan-Werner Müller's idea of a 'Copenhagen Commission' ${ }^{134}$ The proposal concentrated primarily on two shortcomings of the present system: first, the EP intended to define the Article 2 TEU values by setting up a framework of indicators. Second, it would have provided for the Member States to be assessed regularly by an expert group according to a 'DRF Scoreboard'. A 'DRF policy cycle' was also foreseen to assess the EU institutions.

The draft of the DRF Scoreboard outlined some rather general indicators to measure democracy, rule of law and fundamental rights in the Member States, involving existing expert bodies, civil organisations, EU institutions and not least, national parliaments (Articles 6-8). Depending on the scores of the Member States, the draft proposed initiating different proceedings under the Rule of Law Framework, Article 7 (1) or even 7 (2) TEU. Further, the EP suggested that the Commission launch systemic infringement procedures by bundling several infringement cases together. ${ }^{135}$

Of course there are difficulties: In light of the considerable differences between the systems of the Member States with regard to democracy and rule of law, a comprehensive and detailed list of indicators, which claims validity for all Member States, would have been difficult to establish. ${ }^{136}$ Further, the proposal mentioned the Charter as the only indicator for fundamental rights: however, that would have meant an extension of the Charter's scope beyond the limits of Article 51 (1).

Yet the proposal had some obvious advantages. Monitoring all Member States (and the EU institutions as well) would certainly be more just and balanced than criticising only some selected 'suspicious' Member States. The DRF proposal would not have changed the current system of EU values enforcement fundamentally in so far as Article 7 TEU would have remained the main and final tool of sanctioning non-compliance with EU values. However, the political process would have been preceded by an exhaustive legal analysis: this way, expertise and political considerations could have been better balanced. Unfortunately, the Commission has opted for the usual course and refused to initiate any legislative proposal following the

\footnotetext{
${ }^{133}$ European Parliament resolution of 25 October 2016 with recommendations to the Commission on the establishment of an EU mechanism on democracy, the rule of law and fundamental rights (2015/2254(INL)), 8_TA(2016)0409.[DRF Proposal].

${ }^{134}$ Müller (2016), pp. 206-224.

${ }^{135}$ The systemic infringement action was first advised by Scheppele (2013a).

${ }^{136}$ For details about the methodological questions see e.g. Jakab and Lórincz (2017).
} 
EP's DRF-proposal. ${ }^{137}$ The Commission argued that it had 'serious doubts about the need and feasibility' of setting up such annual reports. Further, the involvement of an expert panel raised 'serious questions of legality, institutional legitimacy and accountability,' and rather, 'best possible use should be made of existing instruments while avoiding duplication', the Commission argued. ${ }^{138}$

These arguments are hypocritical for several reasons. First, the Commission presumes that its own Rule of Law Framework does not pose legality and legitimacy concerns. ${ }^{139}$ Second, the Commission is clearly aware of the fact that the existing instruments are not very effective to solve the EU's value crisis, as illustrated by the case of Poland ${ }^{140}$ and Hungary. ${ }^{141}$ The legality and legitimacy concerns could be allayed exactly if Article 7 would result in informed sanctions: and the best way to inform politicians about the legal system of other Member States is a thorough and holistic legal assessment. Further, the judicial dialogue through preliminary proceedings also raised great hopes. Yet, after the LM judgment, ${ }^{142}$ it seems that simply triggering an Article 7 procedure against the affected Member State is not enough to generally overcome the present 'horizontal Solange' model $^{143}$ operating with exceptions from the mutual trust.

By rejecting the DRF proposal, it seemed that the Commission waived the legal assessment in order to keep inappropriate tools of political threat. This raised the question of whether the Commission's position corresponds to its function as guardian of the Treaties. ${ }^{144}$ The proposals on the protection of EU values developed since then, still reflect the need for a thorough legal assessment.

An example for that is the Commission's proposal from 2018 for a regulation to protect 'the Union's budget in case of generalised deficiencies as regards the rule of law in the Member States'. ${ }^{145}$ The proposal aims to withhold payments from EU sources in the case of generalised rule of law deficiencies, trying to find the balance

\footnotetext{
${ }^{137}$ Follow up to the European Parliament resolution on with recommendations to the Commission on the establishment of an EU mechanism on democracy, the rule of law and fundamental rights, adopted by the Commission on 17 January 2017, Ref. no. A8-0283/2016/P8_TA-PROV(2016) 0409 .

${ }^{138}$ See the follow up document no. A8-0283/2016, point 6 .

${ }^{139}$ See e.g. Skouris (2015), p. 14.

${ }^{140}$ In its third Rule of Law recommendation, the Commission admitted that the situation of a systemic threat to the rule of law in Poland has 'seriously deteriorated' since the start of the process. (Commission recommendation no. C(2017) 5320, point 45). This impression definitely was strengthened after triggering Article 7 TEU against Poland-following that efforts made in the frames of the Rule of Law Framework were useless. (Proposal for a Council decision on the determination of a clear risk of a serious breach by the Republic of Poland of the rule of law (2017/ 0360(APP, especially para. 175).

${ }^{141}$ See Sect. 3.1 above.

${ }^{142}$ Case no. C-216/18 PPU (ECLI:EU:C:2018:586).

${ }^{143}$ Canor (2013), pp. 383-421.

${ }^{144}$ Petra Bárd and Sergio Carrera answer this question obviously for the disadvantage of the Commission. See Bárd and Carrera (2017), pp. 9-10.

${ }^{145}$ A8-0469/2018, procedure no. 2018/0136 (COD).
} 
between the general and systemic rule of law violations and the concrete individual cases of fraud or corruption regarding EU sources. In fact, the proposal of the Commission basically foresees a somewhat similar but much simpler political process than that of the Article 7, to be applied to a narrower circle of problems. The main practical differences are that this process has only one stage, the European Council would not be involved and the required majority in the Council would be much lower. In the first reading of the legislative procedure, the European Parliament suggested that both the consent of the Parliament and of the Council should be needed to approve a transfer proposal for a budgetary reserve. ${ }^{146}$

The problem is that the proposal of the Commission explains only very briefly, what is meant under the 'rule of law' or 'generalised deficiency' of the rule of law, which gives ground to restrict the use of EU funds by the affected Member State. Different aspects of the proper functioning of the judiciary system are set out in the proposal: judicial independence, legal remedies, effective investigation and the implementation of judgments, legal certainty, pluralistic and transparent legislative process, lack of arbitrariness and so on. The proposal defines not only legal acts and measures but also 'widespread and recurrent practices and omissions' as possible sources of a generalised rule of law deficiency (Article $2 \mathrm{~b}$ ).

However, it was not clear from the original proposal, how the Commission and the Council would find out whether such a practice takes places in a Member State. The European Parliament made an important amendment at this point and suggested setting up an advisory panel composed of independent experts in constitutional law and financial and budgetary matters, appointed by each of the national parliaments and by the European Parliament (new Article 3 a as proposed). The suggestion clearly reflects the idea of the failed DRF proposal ${ }^{147}$ but applied only to a narrower field, related to rule of law deficiencies affecting the financial interests of the EU.

Regardless of this ongoing legislative process, the Commission seems to realise that it was a mistake to dismiss the Parliament's DRF Scoreboard. It is hard to find any other reason, why the Commission returned to the basic idea of that scoreboard. Namely, in July 2019, the Commission announced the introduction of a 'Rule of Law Review Cycle' and the publication of an 'Annual rule of law report' in order to prevent 'negative developments' regarding the rule of law in the Member States. ${ }^{148}$ Similar to the DRF Scoreboard, all Member States will be subject to this monitoring mechanism, but unlike that scoreboard without a distinct expert panel. Further, the Commission aims at collecting data from existing bodies, also beyond the EU, like the OSCE, the Council of Europe or the EU Fundamental Rights Agency. The reason for that are the Commission's legitimacy and accountability concerns again. In its communication, however, the Commission made clear that 'external expertise cannot take the place of an assessment made by the Commission itself,

\footnotetext{
${ }^{146} \mathrm{New}$ Art. 5, paras. $6 \mathrm{a}-6 \mathrm{c}$ as proposed and Art. 5 paras. $7-8$ as proposed to be deleted.

${ }^{147}$ See Sect. 5.1 above.

${ }^{148} \mathrm{COM}(2019) 343$ final.
} 
particularly when the Commission's conclusions could be the basis for acts that come with legal and financial consequences'.

The question occurs, why extra-EU expert bodies count automatically as accountable and legitimate in the matter of EU values, and how is it guaranteed that the Commission will make an informed assessment concerning the rule of law in the Member States. The first annual rule of law reports, published in September 2020, unfortunately verified these concerns. In the country report on Hungary, the Commission correctly raised criticism concerning a number of issues, but it failed to point out to the big picture: how the criticised elements will affect the constitutional reality in context.

\subsection{How to Indicate Overlapping Systemic Rule of Law Deficiencies?}

To 'measure' the rule of law, it is clearly not enough to 'simply take the Copenhagen criteria off the legal shelf'. ${ }^{149}$ Simple governance checklists do not work either. ${ }^{150}$ However, that is not a reason for giving up any attempts to 'measure' the rule of law. Yet, complex indicators should be used instead of checklists. Aggregating the presence or absence of certain institutional structures does not make much sense without taking into account the wider context and the interrelatedness of different aspects within (and beyond) the rule of law. ${ }^{151}$

Several international rule of law indicators exist, which are based on different factors of the rule of law: still, their results usually are almost identical. ${ }^{152}$ If the EU wants to set up a rule of law indicator, that will be a ground for sanctions, this must be more than a mere checklist. Such a rule of law indicator could only work if it follows a truly holistic approach. The Hungarian example illustrates very well, how many levels of rule of law problems could occur. Particular rule of law problems may affect each other in a way that is extremely difficult to translate into scores and numbers if we work with strictly distinct factors of the rule of law.

For example, targeted legislation seems to be a problem that is relatively easy to detect by assessing to whom a certain law actually applies. Still, the issue becomes more difficult, once the options for constitutional remedies are taken into account. The constitutionality of that targeted law will be reviewed by a Constitutional Court that is composed of judges loyal to the government. Moreover, if the law regulates a financial subject or is part of an 'over-constitutionalisation', it might not be constitutionally reviewed at all. Of course, a weakened Constitutional Court will get lower scores in any system of indicators-but it is questionable whether this lower score

\footnotetext{
${ }^{149}$ Müller (2017), p. 241.

${ }^{150}$ Scheppele (2013b), p. 562 et seq.

${ }^{151}$ Similarly, Ginsburg (2011), p. 272.

${ }^{152}$ See the empirical analysis of Versteeg and Ginsburg (2017), p. 102 et seq.
} 
properly describes its actual effects on the legal system. Such complex outcomes can hardly be expressed in a score-system based on separate factors.

But there is another side of the coin too: if once a constitutional court gets a lower score because of its restricted competences, to what extent does it make sense to complain further about the method of selecting judges? Namely: if the Court could not decide about anything important, why does it matter that it is composed of government-friendly judges? Of course, the question is simplified in so far that some important decisions could surely be made by any constitutional court. Still, if the factors of competence and composition are put in proportion, the final score of a constitutional court will be better balanced.

The correlation and interrelatedness of different factors should not only be measured within the elements of the rule of law (e.g. generality of laws, independence of judges, constitutionalism), but also in the broader context of the state order. For example, it might sound good that two thirds parliamentary majority is needed for appointments for the most important positions and for the amendment of the constitution. But it should also be measured, how easy or how difficult it is to win such a majority in the given election system. By asking this question, we are already beyond the realm of the rule of law, and within the principle of democracy, which is another founding value of the EU. A founding value that seems to be overlooked in the current rule of law debates. And that is a pity for an important reason.

The above-analysed legislative changes are protected by the government always with the same argumentation: they are legitimised by the people to make such reforms and this legitimation does not only establish an opportunity for them, but also an obligation. They must fulfil the people's will by implementing these legislative changes, and anyone who doubts that these reforms comply with the rule of law, actually questions the democratically expressed will of the Hungarian people. As such, they are echoing the idea of 'political constitutionalism' under the slogan of 'illiberal democracy'. However, not only the rule of law, but also the functioning of democracy could convincingly be criticised in Hungary. ${ }^{153}$ The difference between the paradigms of legal and political constitutionalism, between the ideas of 'liberal' and 'majoritarian' democracy was perfectly illustrated through the debates on the Hungarian rule of law. EU institutions could be much more successful in these debates if they distanced themselves from the idea of legal constitutionalism and tried to set a trap for Orbán in his own territory by pointing out to some problems of democratic legitimacy beyond (but related to) the strictly understood rule of law concerns.

Such arguments are more effective if they are not echoed (only) by politicians, but they have a solid background. A background that is more than a report made by a MEP who was bound to party bargains, and more than a mere checklist based on scores of separate factors. A complex EU-indicator of the rule of law (or more

\footnotetext{
${ }^{153}$ E.g. the rules of the election procedure and campaigning (see Sect. 2.1.6 and supra note 113), restrictions regarding direct democracy (supra note 78) and the media situation (supra note 110).
} 
broadly, of EU values) can only be set out if it is sensitive to correlations and it is based on legal reality instead of abstract legal possibilities.

Of course, such an indicator will not be a solution for every problem either. It would also be necessary that the Commission repeatedly launches infringement actions if judgments of the CJEU in rule of law related matters are not respected, and it would further be useful if the CJEU would be more eager to systemically scrutinise the rule of law breaches in those processes. ${ }^{154}$

\section{Conclusion}

As seen above, the Hungarian government works primarily with the instrument of personalised, targeted legislation-this tendency has not been acknowledged in Brussels as one of the main pillars of Hungary's rule of law-deficit. Only some individual pieces of the targeted legal regime reach the thresholds of EU criticism from time to time. The reason for limiting the powers of the Hungarian Constitutional Court was mainly to ensure that the Court does not prevent the introduction of some targeted and politically important laws and constitutional amendments. Ultimately, Hungary has been made subject to an Article 7 procedure. Yet from the Sargentini report it is clear that the rule of law problems of Hungary are only partly captured by the EP: the 'lex CEU' and the 'lex NGO' were the obvious red lines in the eyes of many politicians but they are by far not the most problematic points in the whole constitutional pattern. That pattern could have been identified if EU values would be considered at least worth to be defined-at best, along factors of a scoreboard that takes systemic correlations into account. For Hungary and Poland the purely political Article 7 procedure still awaits-without a minimum of legal certainty provided by clear concepts but with guaranteed political motivations behind the decision. If a final decision comes at all...

\section{References}

Bakó B (2017) Láthatatlan után inkoherens alkotmány. A korlátlan alkotmánymódosító hatalomról [First invisible, then incoherent constitution. On the unlimited constitution-amending power]. Magyar Jog 2017:2

Bakó B (2018) The Zauberlehrling unchained? The recycling of the German Federal Constitutional Court's case law on identity-, ultra vires- and fundamental rights review in Hungary. ZaöRV 78 (4):863-902

Bárd P, Carrera S (2017) The Commission's decision on 'Less EU' in safeguarding the rule of law: a play in four acts. CEPS Policy Insights 1:8

\footnotetext{
${ }^{154} \mathrm{AG}$ Tanchev already criticised the CJEU's approach followed in the infringement case regarding the Polish Supreme Court. See the opinion of AG Tanchev in Joined Cases C-585/18, C-624/18 and C-625/18, A.K., para 147.
} 
Bárd P, Śledzińska-Simon A (2019) Rule of law infringement procedures A proposal to extend the EU's rule of law toolbox. CEPS Papers in Liberty and Security in Europe, 2019-09

Bátorfy A (2017) Az állam foglyul ejtésétôl a piac fogvatartásáig. Orbán Viktor és a kormány médiamodellje 2014 után [From state capture to market capture. The media model of Viktor Orbán and the government]. Médiakutató 2017:1-2

Bellamy R (2007) Political Constitutionalism. A Republican defence of the constitutionality of democracy. Cambridge University Press, Cambridge

Blaskó B (2016) Commentary to $\S 7$ to the Hungarian Criminal Code. In: Polt P (ed) A Büntetô Törvénykönyvról szóló 2012. évi C. törvény nagykommentárja [Great Commentary to Act c. of 2012 on the Criminal Code]. Opten, Budapest

Canor I (2013) My brother's keeper? Horizontal Solange: “An ever closer distrust among the peoples of Europe". Common Market Law Rev 50:383. 2

Erdős C (2013) Visszaélés a jogalkotással - avagy egyedi rendelkezések jogszabályba foglalásának alkotmányossági megítélése [Misuse of legislation - assessing the constitutionality of including individual provisions into law]. Diskurzus 2

Gárdos-Orosz F (2016) Alkotmánybíróság 2010-2015 [Constitutional Court 2010-2015]. In: Jakab A, Gajduschek G (eds) A magyar jogrendszer állapota [The state of the Hungarian legal system]. MTA TK, Budapest, p 2016

Ginsburg T (2011) Pitfalls of measuring the rule of law. Hague J Rule Law 3(2):269-280

Glencross A (2014) The absence of political constitutionalism in the EU: three models for enhancing constitutional agency. J Eur Public Policy 21(8):1163-1180

Halmai G (2012) From 'Rule of Law Revolution' to an illiberal democracy in Hungary. In: Sachs M, Siekmann H (eds) Festschrift für Klaus Stern zum. 80. Geburtstag. Duncker \& Humblot, Berlin

Halmai G (2015) Pártos alkotmánybíráskodás 2010-2014 [Partisan constitutional jurisdiction 2010-2014]. In: Gárdos-Orosz F, Szente Z (eds) Jog és politika határán. Alkotmánybíráskodás Magyarországon 2010 után [At the border of law and politics. Constitutional jurisdiction in Hungary after 2010]. hvg orac, Budapest

Jakab A, Szente Z (2009) Commentary to paragraph 19 § of the constitution. In: Jakab A (ed) Az Alkotmány kommentárja [Commentary of the Constitution], vol 1. Századvég, Budapest

Jakab A, Lórincz OV (2017) International indices as models for the rule of law scoreboard of the European Union: methodological issues. Max Planck Institute for Comparative Public Law \& International Law (MPIL) Research Paper 21/2017

Kochenov D (2017) Busting the myths nuclear: a commentary on Article 7 TEU. EUI Working Paper Law, 2017/10

Müller J-W (2016) Protecting the rule of law (and Democracy!) in the EU. The idea of a Copenhagen Commission. In: Closa C, Kochenov D (eds) Reinforcing rule of law oversight in the European Union. Cambridge University Press, Cambridge

Müller J-W (2017) A democracy commission of one's own, or what it would take for the EU to safeguard liberal democracy in its member states. In: Jakab A, Kochenov D (eds) The enforcement of EU law and values ensuring member states' compliance. Oxford University Press, Oxford

Orbán E (2016) A bírói döntések ellen benyújtott alkotmányjogi panaszok tapasztalatai [Experiences of constitutional complaints directed against judicial decisions]. Pázmány Law Working Papers, 2016/20

Polyák G, Szóke GL (2011) Elszalasztott lehetôség? Az új adatvédelmi törvény fóbb rendelkezései [A missed opportunity? The main provisions of the new data protection law]. In: Drinóczi T (ed) Magyarország új alkotmányossága [The new constitutionality of Hungary]. Pécsi Tudományegyetem Állam- és Jogtudományi Kar, Pécs

Scheppele KL (2013a) What can the European Commission do when member states violate basic principles of the European Union? The case for systemic infringement actions (her proposal is available at the website of the Commission: http://ec.europa.eu/justice/events/assises-justice2013/files/contributions/45.princetonuniversityscheppelesystemicinfringementaction brusselsversion_en.pdf) 
Scheppele KL (2013b) The rule of law and the frankenstate: why governance checklists do not work. Governance 26(4):559-562

Schmitt C (1996) The Tyranny of values. Plutarch Press, Washington DC

Skouris V (2015) Die Rechtsstaatlichkeit in der Europäischen Union [The rule of law in the European Union]. Europarecht Beiheft 2

Sonnevend P, Jakab A, Csink L (2015) The constitution as an instrument of everyday party politics: the basic law of Hungary. In: von Bogdandy A, Sonnevend P (eds) Constitutional crisis in the European constitutional area. Theory, law and politics in Hungary and Romania. Hart Publishing, Oxford

Sulyok T (2016) Erga omnes Effect of Member States' Constitutions and Composite Constitutionality. Fontes Iuris 2016, Special Edition on the FIDE Congress

Szente Z (2016) Die politische Orientierung der Mitglieder des ungarischen Verfassungsgerichts zwischen 2010 und 2014. Jahrbuch für Ostrecht 18(1):45-67

Szente Z (2017) Challenging the basic values - problems in the rule of law in Hungary and the failure of the EU to tackle them. In: Jakab A, Kochenov D (eds) The enforcement of EU law and values. Ensuring member states' compliance. Oxford University Press, Oxford

Tilk P (2014) Az Alkotmánybíróság és a pénzügyi tárgyú törvények vizsgálati lehetôsége [The Constitutional Court and its possibility to review financial acts]. Fundamentum 2014:1-2

Uitz R (2017) Academic freedom in an illiberal democracy: From rule of law through rule by law to rule by men in Hungary. Verfassungsblog, 13. October, 2017

Vadász V (2018) Krízis a bírósági igazgatásban? [Crisis in the judiciary administration?]. MTA Law Working Papers 2018/13

Varga Zs A (2016) Final conferral of sovereignty or limited power-transfer?. Fontes Iuris 2016, Special Edition on the FIDE Congress

Versteeg M, Ginsburg T (2017) Measuring the rule of law: a comparison of indicators. Law Soc Inq 42(1): $100-137$

Vincze A (2013) Der EuGH als Hüter der ungarischen Verfassung - Anmerkung zum Urteil des EuGH 6. 11. 2012, Rs. C-286/12 (Kommission/Ungarn) [The ECJ as the guardian of the Hungarian constitution - A remark to the ruling of the ECJ in case C-276/12 from the 6th of November 2012]. Europarecht 3

Vincze A, Varju M (2012) Hungary: the new fundamental law. Eur Public Law 18:437. 3

von Bogdandy A et al (2012) Reverse Solange - protecting the essence of fundamental rights against EU member states. Common Market Law Rev 49:489. 2

Walker N (2007) Constituent constitutionalism? The case of the European Union. In: Loughlin M, Walker N (eds) The paradox of constitutionalism. Constituent power and constitutional form. Oxford University Press, Oxford

Beáta Bakó is a Max Weber Fellow at the Law Department of the European University Institute, Florence. She is the co-editor-in chief of the Hungarian online newspaper Azonnali.hu.

Open Access This chapter is licensed under the terms of the Creative Commons Attribution 4.0 International License (http://creativecommons.org/licenses/by/4.0/), which permits use, sharing, adaptation, distribution and reproduction in any medium or format, as long as you give appropriate credit to the original author(s) and the source, provide a link to the Creative Commons license and indicate if changes were made.

The images or other third party material in this chapter are included in the chapter's Creative Commons license, unless indicated otherwise in a credit line to the material. If material is not included in the chapter's Creative Commons license and your intended use is not permitted by statutory regulation or exceeds the permitted use, you will need to obtain permission directly from the copyright holder.

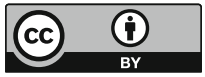

